\title{
AZ ELŐZETES TUDÁS ELISMERÉSÉNEK \\ (VALIDATION DES ACQUIS DE L'EXPÉRIENCE) GYAKORLATA FRANCIAORSZÁGBAN
}

\section{BENKEI KOVÁCS BALÁZS}

az Eötvös Loránd Tudományegyetem Pedagógiai és Pszichológiai Karának

doktorandusz hallgatója

kovacsbalazs18@t-online.hu

\begin{abstract}
A tapasztalati úton megszerzett elözetes tudás elismerése egy tanulási eredményekre épülö oktatási rendszerben komoly szerepet játszhat. A 2002 óta müködö francia gyakorlat, nemzeti néven a validáció, egy olyan felnöttoktatási nóvum, amely európa és világszerte - az összes felmerülö aggály ellenére - komoly elismerést váltott ki a szakemberek részéröl. A francia országjelentés, amely a Confitea VI. belémi felnöttnevelési vliágkonferenciájára készült, is ezt az újitást emeli ki az útóbbi évtized legfontosabb reformjai közül. A tanulmány átfogó és koherens képet próbál adni a validáció jelentőségéről, alapvető pedagógiai és szociológiai vonatkozásairól, az eszköz gyakorlati müködéséröl, és az elsö évek alkalmazása után tapasztalható eredményekröl.
\end{abstract}

\section{Bevezetés}

Az Európai Unióban az egész életen át tartó tanulás szellemében az ismeretek forrásától és megszerzésének módjától függetlenül felértékelődött a tudás. A nem formális úton szerzett ismeretek intézményesített keretben történő elismerésével kapcsolatban a partnerországok közös alapelveket fogadtak el 2004 májusában, ${ }^{1}$ a gyakorlati megvalósítás útján azonban minden ország más-más fázisban tart. ${ }^{2}$

Az utóbbi években számos nagy nemzetközi felnőttképzési kutatás fókuszába került a jelenség, amelyek közül a Grundtwig-projekt keretében megvalósított Reaction-projektet szeretném kiemelni. A 2005 és 2007 között megvalósított Reaction-projekt célja, hogy komparatív andragógiai szempontból vizsgálja a tapasztalati úton megszerzett tudás elismerését és beszámíthatóságát (recognition and accreditation of experiental learning), amely folyamatot a felnőttképzésbe való bekapcsolódás egy alternatív útjának tekintik. A projekt keretében egy litván egyetem - a Vyatus Magnus University - koordinálta a fejlesztő munkát észtországi, ír, spa-

\footnotetext{
${ }^{1}$ Common European Principles for Validation of non-formal and informal learning, http://www.eaea. org/news.php?k=3224\&aid=3224. (letöltve az internetröl 2009. január 15.)

2 European Inventory on Validation: 2007 Update / http://www.ecotec.com/europeaninventory/2007. html. (letöltve az internetröl 2009. január 15.)
} 
nyol, belga, holland és olasz oktatási partnerintézményekkel együttmüködve. A projektben a különféle országokban megvalósított gyakorlat és jogszabályi háttér bemutatása mellett számos új andragógiai eszközt is kidolgoztak, mint például egy tanár-továbbképzési curriculumot azon oktatók és szakemberek részére, akik az elözetes tudás felmérésének értékelési fázisában vizsgáztatóként, valamint tutorként vesznek részt (Tereseviciene, 2007).

Magyarországon nemrég indultak meg az ilyen irányú kutatások (Derényi et al., 2007; Csapó, 2005), azonban az előzetes tudás elismerésének fogalma korábbról sem ismeretlen a hazai pedagógiai és andragógiai szakirodalomban.

A jelenséget a hazai szakirodalomban gyakran francia sajátosságként mutatják be, ami arra vezethető vissza, hogy Franciaországban a 80-as évek közepétől van már hagyománya a korábbi tudás intézményesített formában történő elismerésének. A Felnöttképzési lexikon (Benedek, 2002), a Felnöttképzés az Európai Unióban (2004) címü kézikönyv és Farkas Éva (Farkas, 2006) összegző jelleggel ismerteti, míg Bajomi Iván (Bajomi, 2002) egy egész tanulmányban vizsgálja az előzetes tudásszint felmérésének gyakorlatát Franciaországban.

Az előzetes tudás elismerésének azt a franciaországi gyakorlatban kialakult fajtáját, amely a tapasztalati úton történő tanulás egy andragógiai értékelésmódszertani eszköze (francia nevén Validation des acquis de l'expérience, rövidítve VAE), a tanulmány hátralévő részében röviden validációs eljárásnak hívjuk. A validációs eljárás folyamán egy szakértői bizottság jól meghatározott kritériumok alapján egy adott szakterületre vetítve vizsgálja az életpálya során felhalmozott szakmai készségeket, jártasságokat és kompetenciákat, és pozitív eredmény esetén az eljárásban részt vevő személy részére államilag elismert szakképzettséget igazoló bizonyítványt vagy diplomát állít ki.

Először 1985-ben jelent meg törvényi szinten a korábbi tudás és tapasztalat elismerésének fontossága a francia oktatáspolitikában, ami akkor még csupán az egyetemre való bekerülést, a felvételi vizsga alóli mentességet tette lehetővé. 1992ben a validációs rendszer fejlesztése újabb állomásához érkezett: a korábban elsajátított tudás vagy a korábbi szakmai gyakorlat alapján - jól meghatározott kritériumoknak megfelelően - egy képzésen belül a moduláris rendszerbe tagozódó szakképzettségek és diplomák bizonyos elemeinek megszerzése alól felmentést lehetett szerezni az értékelés-módszertan eme alternatív eszközével. Ez a módszertani eszköz az elözetes szakmai tudás elismeréseként (Validation des acquis professionnels - VAP) került be az andragógiai szakirodalomba. A teljes szakképzettség megszerzésére ilyen módon még nem volt lehetőség, legalább egy modult a hagyományos iskolarendszerü képzés keretén belül teljesíteniük kellett az érintetteknek (Gourmelen, 2006). 
2002 januárjában született meg az a társadalmi modernizációs törvény (la loi de la modernistation sociale ${ }^{3}$, amely lehetővé teszi, hogy a validációs eljáráson keresztül a teljes diploma vagy szakképzettség megszerezhetö legyen oly módon, hogy ahhoz egyetlen klasszikus értelemben vett vizsgamodult sem kell teljesíteni. Ezt az újítást teljes nevén az elözetes tapasztalati tudás elismeréseként (Validation des acquis de l'expérience - VAE) vezették be.

A törvénymódosítás hátterében nem csupán az új andragógiai módszerek iránti elkötelezettség, hanem az alábbi meghatározó társadalmi okok állnak (Dumont Le Douaron, 2006):

- a lakosság 30\%-ának nincs diplomája, de megfelelően képzettek egy munkakör betöltésére,

- a munka melletti továbbképzés rendszerint rövid időtartamú, és nem jár újabb végzettség megszerzésével,

- a munka melletti továbbképzéseken a „fehérgalléros” hivatali alkalmazottak $70 \%$-a, míg a fizikai munkások $80 \%$-a nem jut megfelelö rendszeres képzéshez,

- számos munkavállaló, aki nem kíván visszatérni az „iskolapadba”, megfelelő ismeretekkel és gyakorlatban alkalmazható tudással rendelkezik a korábban megszerzett szakmai tapasztalatainak köszönhetően,

- az új eszköz elterjedésével számos olyan, a képzésekhez való hozzáférés tekintetében hátrányos helyzetü célcsoportot lehetne bevonni a felnőttképzésbe, mint az alacsony végzettségü munkavállalók csoportja.

Ezeket a problémákat és egyenlőtlenségeket a szakképzés-felnőttképzés klasszikus eszközeivel már nem lehet orvosolni. Amíg a hagyományos iskolarendszerü szakképzettséget adó végzettség a formális tanulási periódust zárja le, és elsősorban fiatalok képzésére tervezték, a nem formális és az informális tudás elismertetésére a validációs eljárás szolgál Franciaországban, amelyet eredendően a felnőttek számára alakítottak ki.

„A hátrányos helyzetű rétegek felemelkedésében meghatározó jelentősége van annak, hogy a bennük rejlő képességek, szinte észrevétlenül megszerzett tudások csak egy olyan oktatási és képzési rendszerben hasznosíthatóak igazán, amely nem azt vizsgálja, hogy milyen formális képzési utakon szerezték azokat, hanem azt, hogy azok mennyire teszik alkalmassá e tudások birtokosát a munka világában betöltendő különféle szerepekre.” (Schüttler, 2008)

A validációs eljárás Franciaországi bevezetésének három legfőbb célját a következő pontokban foglalhatjuk össze: 1) mennyiségileg növelni, minőség tekintetében pedig javítani az aktív munkavállalók végzettségi szintjét; 2) létrehozni a

\footnotetext{
${ }^{3}$ A 2002. január 17-én hatályba lépett társadalmi modernizációs törvény 133-146. §-a szabályozza a validációs eljárást.
} 
szakmai mobilitás esélyét az alulképzett csoportok számára is; 3) a munkahelyek megőrzése tekintetében biztonságosabbá tenni az életpályán átívelő szakmai karrierutakat.

A validációs eljárás kialakítása egy hosszú távú stratégiai döntés eredménye, ugyanis egyrészről valóban szélesebb rétegeket fog bevonni a felnőttek képzésbe, másrészről közép és hosszú távon a képzési kínálatot is gyökeresen át fogja alakítani, még ha ebben bizonyos képzőintézmények pillanatnyilag ellenérdekeltek is.

\section{A validációs eljárás pedagógiai és szociológiai szempontból}

A hagyományos pedagógiai folyamatok visszájára fordulnak a validációs eljárás keretében. A „klasszikus iskolarendszerü képzés” az elméleti háttér meglapozásával kezdődik, amelyet a vállalatoknál kihelyezett gyakorlati időszakok követnek. Az iskolán kívül végzett gyakorlat „,megmérettetés”-jelleget ölt: a tanuló az elméleti ismereteket ütközteti a munka világának valóságával. Ebben az esetben egy deduktív jellegü pedagógiai folyamatról van szó, a kompetenciák kialakításáról.

Ezzel szemben a validációs eljárás induktiv logikájú pedagógiai eszköz: a tapasztalat válik az elsődlegessé, az elméleti ismeretek másodlagosak, nagyobb részben az elvégzett munka során végrehajtott feladatok értelmezésére fordítanak figyelmet. A tutorok nem tanítanak, hanem rávezetik a résztvevőt a szakmai tapasztalatok rendszerezett elemzésére és a szakmai önértékelésre. A folyamatot a résztvevőközpontúság határozza meg: az elemzés a személyes szakmai tapasztalatokra épül, amelyekhez az elméleti ismeretek, kérdések, technikai javaslatok kapcsolhatóak, és amelyek az egyén rendszerező és reflektív elemzése következtében válnak az adott kritériumoknak megfelelően értékelhetővé (Dennery, 2004). Az induktív jellegü pedagógiai folyamatban a gyakorlati szaktudás hitelesítése történik meg.

Az egyén szempontjából - Gourmelen szociológiai látásmódja (Gourmelen, 2006) alapján - szimbolikus jelentősége lehet a validációs eljáráson történő részvételnek. Az egyén igazából nem változik, de a „többiek tekintete”, a mód, ahogyan „kezelik ôt” ezek után - mint végzettséggel rendelkező munkavállalót - igen. A validációs eljárásban részt vevő személyeknek $60 \%$-a ugyanis a „képzettség nélküliek” csoportjából a „végzettséggel rendelkezők” csoportjába kerül át, ami egyszerre ad a szakmai kompetenciákat tekintve biztonságérzetet, önbizalmat, nagyobb társadalmi megbecsültséget és egy sikeres karrierút érzetét.

\section{A validációs eljárás müködése a gyakorlatban}

A validációs eljárás során a beszámított tudáselemek származhatnak korábbi munkahelyi tapasztalatokból, egyesületi vagy civil szervezeteknél elvégzett önkéntes tevékenység közben megszerzett ismeretekböl. Ahhoz, hogy a korábbi szakmai te- 
vékenység elismertethető legyen, hároméves folyamatos, az adott területen és munkakörben töltött aktív idöszak igazolása szükséges.

A validációs eljárás folyamatában első lépésben a jelentkezők tájékoztatása és előzetes felmérése történik meg az e célból létrehozott információs pontoknál, ahol felnőttképzési tanácsadók fogadják az érdeklődőket. Megállapítják, hogy a jelentkező - tapasztalatai alapján - milyen munkaköri leírásoknak megfelelően végzett munkát, és ez milyen képzettséggel párosul. A jelölt egy felnőttképzési tanácsadóval egyeztetve meghatározza az elérendő képzési céljait, a reális lehetőségek figyelembevételével. A felnőttképzési tanácsadó segítségével kiválasztják a legmegfelelőbb tanulási módot, figyelembe véve a jelölt életkorát, személyes igényeit, korábbi tanulmányait és egyéb lehetőségeit (szendvics típusú képzés, nappali képzés, távoktatás vagy a validációs eljárás megindítása), ezzel tulajdonképpen lezajlik a validációs eljárásra történő jelentkezés előzetes bírálata (dossier de recevabilité).

A validációs eljárás megindítása esetén a képzési célként kiválasztott végzettségnek szerepelnie kell a francia Szakmai Képesitések Nemzeti Jegyzékében (Répertoire National des Qualifications Professionnelles - RNCP). Minden ilyen képzettséghez tartozik egy munkaköri leírás (Référentiels des Emplois, Activités at Compétences - REAC), amely az adott munkakör ellátásához tartozó kompetenciaprofilt írja le részletesen, illetve egy központi vizsgakövetelmény (Référentiel de Certification - RC). A jelöltet egy tutor ezen dokumentumoknak megfelelően készíti fel, illetve nyújt neki támogatást a vizsgaportfólió anyagának összeállításában. A tutorral a fél-egy év időtartamú felkészülés alatt négy-öt alkalommal történik konzultáció, a jelöltnek a portfólió szisztematikus összeállítását a szabályok szerint önállóan kell elvégeznie.

A portfólió összeállítását követően egy képzőkből és az adott terület szakembereiből összeállított vegyes bizottság ellenőrzi és értékeli a jelölt kompetenciáit az írásbeli portfólió megvizsgálásával. A jelölt munkahelyi környezetben gyakorlati szakmai vizsgán vesz részt, amely történhet a munka típusától függően tantermi, gyakorlóhelyi, avagy tényleges munkahelyi környezetben, valamint bemutatja az összeállított portfóliót a bizottság előtt egy szóbeli vizsgabeszélgetés alkalmával.

A sikeres validációs eljárás végén az előzetes tudás elismerése teljes vagy részleges formában történhet meg. A portfólió maradéktalan elfogadása esetén szakmai végzettség birtokába jut a jelölt. A részlegesen elfogadott szakmai portfólió esetén a hiányzó modulok teljesítésére további öt évig van lehetőség, azt követően elévül a bizottság határozata. 
1. táblázat: A validációs eljárás főbb lépései a jelölt szemszögéböl (Gourmelen, 2006, 291-302. o.)

\begin{tabular}{|c|c|}
\hline $\begin{array}{l}\text { A validációs eljárás } \\
\text { föbb lépései }\end{array}$ & A jelölt fö feladatai az adott időszakban \\
\hline $\begin{array}{l}\text { 1. A tapasztalatok } \\
\text { összegyüjtése }\end{array}$ & $\begin{array}{l}\text { Összeállítani a validációs eljárásra történő jelentkezés } \\
\text { elözetes bírálatához szükséges dokumentumokat, kiválasztani } \\
\text { az elérendő végzettséget (dossier de recevabilité). }\end{array}$ \\
\hline $\begin{array}{l}\text { 2. A validációs eljárás } \\
\text { megindítása }\end{array}$ & $\begin{array}{l}\text { Megindítani a validációs eljárást egy meghatározott végzett- } \\
\text { ség megszerzése céljából, első konzultáció a tutorral, az } \\
\text { eljárás időbeosztásának és finanszírozásának megtervezése. }\end{array}$ \\
\hline $\begin{array}{l}\text { 3. A munkavégzési } \\
\text { gyakorlat elemzésé- } \\
\text { nek első fázisa }\end{array}$ & $\begin{array}{l}\text { Összevetni a mindennapi munkavégzés gyakorlatát } \\
\text { a munkaköri leírással és a szóbeli normákkal }\end{array}$ \\
\hline $\begin{array}{l}\text { 4. A munkavégzési } \\
\text { gyakorlat elemzése } \\
\text { a referenciadoku- } \\
\text { mentumokhoz } \\
\text { viszonyítva }\end{array}$ & $\begin{array}{l}\text { Elhelyezni a munkavégzési gyakorlatot a központi munkaköri } \\
\text { leírásoknak, a kompetencia- és feladatprofilnak megfelelöen. } \\
\text { Meghatározni azokat a munkafeladatokat, amelyek a gyakor- } \\
\text { latban nem merültek fel, illetve amelyek rutinszerúen rög- } \\
\text { zültek, feltárni a kompetenciaprofil alapján a hiányokat és } \\
\text { a fejlödési irányokat. }\end{array}$ \\
\hline $\begin{array}{l}\text { 5. Felkészülés } \\
\text { a gyakorlati } \\
\text { vizsgarészre }\end{array}$ & $\begin{array}{l}\text { Kidolgozni a gyakorlati feladatok megoldásának modelljét, } \\
\text { mind a munkahelyi gyakorlat alapján rutinszerúen rögzült, mind } \\
\text { a kevésbé ismert munkafeladatok esetében, figyelembe véve } \\
\text { a központi munkaköri leírásoknak (REAC) a munkafelada- } \\
\text { tokra és a kompetenciákra vonatkozó elöírásait. }\end{array}$ \\
\hline $\begin{array}{l}\text { 6. Az értékelési } \\
\text { rendszer } \\
\text { megismerése }\end{array}$ & $\begin{array}{l}\text { Megismerkedni az értékelési rendszer kritériumaival, } \\
\text { ha lehetséges, felkeresni a gyakorlati vizsgarész helyszínét } \\
\text { „terepszemle” céljából. }\end{array}$ \\
\hline $\begin{array}{l}\text { 7. Gyakorlati vizsgarész } \\
\text { munkahelyi } \\
\text { környezetben }\end{array}$ & $\begin{array}{l}\text { Megmérettetni egy munkahelyi feladat elvégzése közben, } \\
\text { a munka típusától függöen tantermi, gyakorlóhelyi, avagy } \\
\text { tényleges munkahelyi környezetben. }\end{array}$ \\
\hline $\begin{array}{l}\text { 8. A gyakorlati vizsga } \\
\text { eredményének } \\
\text { elemzése }\end{array}$ & $\begin{array}{l}\text { Elemezni a gyakorlati vizsgarész értékelését, feldolgozni } \\
\text { a vizsgáztatók útmutatásait és, ha szükséges, kifogásait - } \\
\text { megoldási javaslatokat keresve. }\end{array}$ \\
\hline $\begin{array}{l}\text { 9. Részvétel } \\
\text { a záróvizsgán }\end{array}$ & $\begin{array}{l}\text { Záró vizsgabeszélgetés a bizottság elött, a portfólió } \\
\text { bemutatása. }\end{array}$ \\
\hline $\begin{array}{l}\text { 10. A vizsgabeszélgetés } \\
\text { eredményének elemzése }\end{array}$ & $\begin{array}{l}\begin{array}{l}\text { Feldolgozni a záróvizsga értékelését, és az eredményeket, } \\
\text { szükség esetén hibákat elemezni. }\end{array} \\
\end{array}$ \\
\hline $\begin{array}{l}\text { 11. A validációs eljárás } \\
\text { lezárása }\end{array}$ & $\begin{array}{l}\text { A végzettség teljes vagy részleges megszerzése vagy } \\
\text { elutasítása. }\end{array}$ \\
\hline
\end{tabular}




\section{A validációs eljárás első éveinek eredményei}

A validációs eljárás törvényi létrehozását követően először is ki kellett alakítani egy olyan országos tanácsadó hálózatot, amely a potenciális jelölteket informálja. A tájékoztatási kampány feladatát országszerte a 2004-ben létrehozott, 23 régióban megoszló 800 információs pont látta el. A közszolgálati tájékoztató hálózat mellett az egyes képzőintézményeket is (felnőttképzőket és a felsőoktatási intézményeket egyaránt) kötelezték tájékoztatási szolgáltatásaik ilyen irányú bővítésére.

2003-2006 között háromszázezer érdeklődő tájékoztatása történt meg, és közülük több mint 45 ezren szereztek szakmai végzettséget sikeres validációs eljárás következtében. A validációs eljárásra jelentkezők szociológiai jellemzőinek vizsgálatakor kitünik, hogy több mint kétharmaduk nö, egyharmaduk munkakereső volt 2004-ben. ${ }^{4}$ Ez pozitív eredményként értékelhető, hiszen a tapasztalat azt mutatja, hogy a korábban említett hátrányos helyzetü csoportok a felnőttképzés ezen eszközével valóban élni tudnak. A jelöltek életkori megoszlásuk tekintetében 70\%-ban a 30 és 49 év közötti korcsoporthoz tartoznak, 60\%-ban az első végzettség (szakképzettséget igazoló bizonyítvány vagy diploma) megszerzésére törekednek.

A bevezetést követő első évek tanulságai számos kettősséget hordoznak. Siker, hiszen sok végzettséget szereztek meg a validációs eljárás által. Ezek ugyanakkor még csupán nagyságrendi és nem pontos adatok, hiszen a részleges szakképesítést megszerzők számára további öt év áll rendelkezésre, hogy a nem elfogadott modulokat teljesítsék. Vajon közülük az öt év letelte után hányan szerzik majd meg a szakképesítést vagy a diplomát, és hány olyan vizsgázó lesz, aki az első kudarcok után újra hátat fordít a tanulásnak és a vizsgázásnak, ezúttal talán végérvényesen?

Ugyanakkor némi csalódás is tapasztalható. A validációs eljárás ugyanis nem „csodaszer”, nem lehet szociális ugródeszka mindenki számára. Jól meghatározott munkaköri leírások, kompetenciamérleg-készítés, szakmai portfólió összeállítása előzi meg a végső szóbeli záróvizsgát, amelyre sokkal alaposabban fel kell készülni, mint egy hagyományos egyetemi kollokviumra, ráadásul a tutori iránymutatás mellett zajló felkészülés legnagyobb részét mégis önállóan kell elvégezni. Ezen a ponton újra megerösíthető, hogy nem ,ingyen diplomaosztásról” van szó, hanem egy igen behatárolt szakmai területen a korábban elvégzett munka elismertetéséröl, bizonyos fokú szakmai előrelépésről, amelyhez azonban újra kell gondolni az elmúlt évek munkatapasztalatait, azokat bemutatni, és nem utolsósorban összevetni a saját munkavégzés gyakorlatát az adott munkakörrel járó feladatrepertoárral - ami nem megy alapvető absztrakciós és előadói készség nélkül. Ez utóbbi két készség

\footnotetext{
${ }^{4}$ Ezáltal a módszer megoldását adja a vállalati továbbképzéseket illető klasszikus szociológiai kritikának, mely szerint „egy középkorú, végzettséggel nem rendelkező női munkavállalónak, aki egy tíz főnél kevesebb dolgozót foglalkoztató mikrovállalatnál dolgozik, 25-ször kisebb az esélye, hogy továbbképzésben vegyen részt, mint egy minősített végzettséggel rendelkező, nagyvállalatnál dolgozó fiatal férfinak". (Gourmelen, 2006, 35. o.)
} 
szükségességét egyébként a szakirodalomban a validációs eljárás gyengéjeként is felemlegetik, hiszen a leghátrányosabb munkavállalói rétegeknél, mint például a betanított fizikai munkásoknál az absztrakciós és szóbeli előadói készség előhívása - ráadásul az általuk a mindennapi gyakorlatban ritkán használt formális szóbeli kommunikáció stílusrétegében és egy hivatalos vizsgabizottság elött - nehézséget szokott okozni. Persze a vállalati gyakorlat talál megoldást ezekre a helyzetekre is.

Az elözetes tudásszintfelmérés módszertana nem oldja meg a szakképzettség vagy a szakképzési rendszer problémáit, azonban annak tökéletlenségeit finomítja. Társadalmi és gazdasági szempontból nagy jelentőségü, hogy az egyéni mód mellett kollektív formában is lehet a validációs eljárásra jelentkezni. Ezekben az esetekben - kissé hasonlóan a vállalati továbbképzések logikájához - leggyakrabban maguk a munkáltatók, pontosabban a humánerőforrás-menedzsment ,iskolázza be” a munkavállalókat csoportos formában.

A fel-felbukkanó negatív vélemények ellenére többségében üdvözölték mind a felnőttképzők, mind a munkáltatók, mind a munkavállalók a felnőttképzésnek ezt az új útját, amelynek széles körü elterjedéséhez alapvető reményeket füznek.

\section{A vállalati alkalmazás első lépései}

A nagy cégek humánerőforrás-menedzsmentje számára a validációs eljárás kollektív alkalmazása több szempontból is kedvező. Egyrészt a HR-esek rendelkeznek olyan homogén csoportokkal, amelyeket be tudnak iskoláztatni a validációs eljárás kertében (pontos információkkal rendelkeznek róla, hogy melyik osztályon, hányan és milyen régóta dolgoznak egy adott munkakörben), ráadásul ehhez a képzési tevékenységhez a szakképzési hozzájárulás terhére forrásokat is igénybe tudnak venni. Másrészről ahelyett, hogy 500 tanórás (egy átlagos, alacsonyabb szintü szakképzés időtartama) vagy 1200 tanórás (egy felsőfokú technikusi képzés időtartama) tanfolyamot kellene anyagilag támogatniuk, csupán a fajlagosan rövid ideig tartó validációs eljárásra történő felkészítés és vizsgáztatás díjai terhelik őket. A megszerzett végzettség azonos, ugyanakkor alacsonyabb költségvetéssel és a munkavállalók rövidebb távollétével jár.

A jelen tanulmány keretein belül csupán három példaértékkel bíró nagyvállalatot szeretnénk kiemelni (Combes, 2008):

- Az Auchan hipermarket ${ }^{5}$ bolti eladók képzését vitte véghez a validációs eljárással, a módszer alkalmazása ugyanakkor a belső promóció eszköze is volt. A HR-vezetés a munkavállalók korábbi teljesítménye, illetve a velük való jövőbeli elképzelések alapján választotta ki a validációs eljárásra a jelölteket. Objektíven mérlegelve ez a gyakorlat nem biztos, hogy teljes mértékben az esélyegyenlőséget szolgálta.

\footnotetext{
${ }^{5}$ La VAE chez Auchan: Une démarche expérimentale, in Les politiques des entreprises, 11-20.
} 
- A Flunch önkiszolgáló étteremlánc ${ }^{6}$ az alapvető vendéglátós végzettséggel nem rendelkező betanitott munkások számára alkalmazta a validációs eljárás eszközét. A HR-vezetés deklarált célja, hogy minden dolgozójuk szakképesített legyen, az új humánerőforrás-igazgató jelszava: „szakképzettséggel a minőségért", így itt két kiválasztott étteremben az azonos területen dolgozó összes alkalmazott beiskolázása megtörtént. Az elkövetkezendő években a többi étteremre is ki szeretnék terjeszteni ezt a képzési formát.

- A Manpower munkaközvetítő cégcsoport franciaországi képviselete ${ }^{7}$ egy egészen különleges területen, a határozott időre szerződtetett betanított munkások között alkalmazta a validációs eljárást csoportos formában. A határozott időre szerződtetett munkavállalók (,intérimaire”) nem alkalmazhatóak egy cégnél másfél évnél hosszabb ideig, azonban a munkaközvetítő céggel ennél lehet hosszabb idejü szerződésük is. Ezt használta ki a Manpower menedzsmentje, és a validációs eljárás célja az volt, hogy a szerződéses törzsgárdáját - a targonca- és kisgépkezelö betanított munkások körében - fidelizálja. A képzés nagy sikert aratott: a munkaközvetítő cég számításai nem teljesültek maradéktalanul, a munkavállalókéi annál inkább, mivel a képzettséggel rendelkező betanított munkások egy részét aktuális munkaadóik véglegesítették.

Első alkalommal a vállalatok kisebb dolgozói populáción „tesztelték” az új andragógiai módszert. A résztvevők számát és a képzési időszakokat a 2. sz. táblázat szemlélteti.

2. táblázat: A validációs eljárás kísérlete három vállalat gyakorlatában (Combes et al., 2008, 8-9. o.)

\begin{tabular}{|l|c|c|c|}
\hline \multicolumn{1}{|c|}{ A vállalat neve } & Auchan & Flunch & Manpower \\
\hline $\begin{array}{l}\text { A validációs eljárásban } \\
\text { részt vevők száma }\end{array}$ & 23 fö & 54 fö & 39 fö \\
\hline Gazdasági szektor & kereskedelem & vendéglátóipar & szolgáltatóipar \\
\hline A képzés időszaka & $2006-2007$ & 2005 & 2005 \\
\hline
\end{tabular}

A módszer vállalati alkalmazásánál a viszonylag homogén csoportok „készültek fel" kollektíven. A jelöltek tudásbeli deficitjének ismeretében a humánerőforrásmenedzsment más-más eszközökkel próbálta segíteni őket, ami helyenként már túllépett az esélyegyenlőség biztosításán is. Például a Flunch étteremlánc jelöltjeinél a

\footnotetext{
${ }^{6}$ Flunch: la Validation des acquis de l'expérience dans le contexte d'une nouvelle politique de gestion des ressources humaines, uo., 27-34.

${ }^{7}$ Une opération collective chez Manpower, uo., 99-108.
} 
vizsgabeszélgetés a munkahelyi környezetben zajlott le, a jelöltek portfóliójának vizsgálatakor a záróvizsga alkalmával csupán a vizsgabizottság volt jelen, a jelölteknek nem kellett szóbeli vizsgát tenniük. Joggal merül fel a kérdés: vajon meddig szabad elmenni a jelöltek támogatásában az önállóan elvégzendő munka kárára, amelynek értékelése tulajdonképpen a módszer lényege?

A jogi keretszabályozás hézagainak pótlásához, a visszásságok elkerülése érdekében Franciaországban is fokozatosan tovább kell majd pontosítani a rendszert.

\section{Összegzés}

Összességében sikeresnek ítélhető meg ezen andragógiai értékelés-módszertani eszköz bevezetése a törvény létrehozása után hét év távlatából visszatekintve, még ha a rendszer finomhangolására a gyakorlatból adódó sajátosságok miatt a továbbiakban is szükség lesz. Számos diploma kiosztása a felnőttképzés hátrányos helyzetben lévő résztvevője számára, valamint a tény, hogy a társadalom, a pedagógusszakma és maguk a felnőttképzésben részt vevők is egyre jobban ismerik és elismerik a validációs eljárást - igazolja a sikert.

Mai szemmel egyetlen komoly kritikát lehet megfogalmazni a validációs eljárással kapcsolatban, de az nem az andragógiai módszerből magából, hanem annak pillanatnyi alkalmazhatóságából adódik: a validációs eljárást a teljes foglalkoztatottság felé haladó társadalom szellemében, annak jobbítása céljából fejlesztették ki. Így lehet, hogy az elkövetkező egy-két évben - a gazdasági helyzet bizonytalanságából kifolyólag - nem az első körben vezetik majd be hazánkban ${ }^{8}$ a szakképzési reformok között.

Ugyanakkor a magyar kormány 2005-ben elkészített „lifelong learning” stratégiájában szerepelt már (az 1.2.2. pontban), valamint a 2005-2013 közötti időszakra készített szakképzés-fejlesztési stratégiája is kimondja explicit módon a megszerzett tudás beszámításának fontosságát (Derényi et al., 2007). Mivel minden krízis, akárcsak a prosperitás időszakai, átmeneti, el fog jönni az idő, amikor az EU

\footnotetext{
${ }^{8}$ Jelenleg a magyar gyakorlatban igazából még ismeretlen a validációs eljárás, és a hazai felnőttképzésben mást értünk az előzetes tudásszint felmérése alatt, egyfajta „felvételi kritériumként” szerepel: a 2001 januárjától hatályos felnőttképzési törvény 17. §-a értelmében ,a képzésre jelentkező felnőtt kérheti tudásszintjének előzetes felmérését, amelyet a felnőttképzést folytató intézmény köteles értékelni és figyelembe venni”. Sem a jogszabály, sem más, kapcsolódó végrehajtási dokumentum nem tartalmazza azonban annak kifejtését, hogy milyen módon, kinek a költségére történik az értékelési eljárás, mit jelent a figyelembevétel, és mi történik akkor, ha a képzőintézmény egyáltalán nem végez ilyen tevékenységet [...]. A felnőttképzési törvény révén a kormányzat a képzési tevékenység szerves részévé kívánta tenni a felnőttképzési szolgáltatásokat. Az előzetes tudásértékelés [...] lényegében a képzési program indulásához szervesen kapcsolódó szakasz, amelynek elsődleges célja a „képzést végzö szakemberek tájékoztatása arról, hogy milyen felkészültségü résztvevőkkel kell megvalósitaniuk az adott képzési programot”. (Derényi et al., 2007. 40-41. o., http://www.okm.gov.hu/doc/upload/ 200804/nem_formalis_es_informalis_080414.pdf.)
} 
iránymutatásait követve egy ilyen típusú átgondolt reform bevezetésére hazánkban is sor kerül. Ekkor a francia példa számos hasznos tanulsággal szolgálhat majd a hazai szakemberek számára.

\section{Irodalom}

Bajomi Iván (2002): „Az iskolán kívül elsajátított készségek és tudások elismertetése Franciaországban", Új Pedagógiai Szemle, 11. sz. 115-121.

http://www.oki.hu/oldal.php?tipus=cikk\&kod=2002-11-vt-Bajomi-Iskolan (letöltve az internetről 2009. január 15.).

Benedek András et al. (szerk., 2002): Felnőttoktatási és -képzési lexikon. Magyar Pedagógiai Társaság, OKI Kiadó, Szaktudás Kiadó Ház, Budapest.

Csapó Benő (2005): Az elözetesen megszerzett tudás mérése és elismerése. NFI, Budapest.

Dennery, M. (2004): Réforme de la formation professionnelle. ESF, Issy-les-Moulineaux.

Derényi et al. (2007): A nem formális és informális tanulás elismerése Magyarországon. Egy OECD projekt tanulságai. OKM, Budapest.

http://www.okm.gov.hu/doc/upload/200804/nem_formalis_es_informalis_080414.pdf (letöltve az internetröl 2009. január 15.).

Farkas Éva (2006): A felnöttképzés felértékelödése az emberi eröforrás-fejlesztés folyamatában. PTE-FEEK, Pécs.

Gourmelen, B. (2006): La validation des acquis de l'expérience. L'Harmattan kiadó, Párizs.

Combes et al. (2008): Les politiques des entreprises en matière de certification et l'utilisation de la validation des acquis de l'expérience. Net Doc sorozat, Céreq kiadó, 34. sz., 2008 február), http://www.cereq.fr/cereq/Net-Doc-34.pdf (letöltve az internetröl 2009. január 15.).

Dumont, J.-F. - Le Douaron, P. (szerk., 2006): Premiers éclairages sur la réforme de la formation professionnelle. Francia Munkaügyi Minisztérium. http://lesrapports.ladocumentationfrancaise.fr/BRP/064000888/0000.pdf (letöltve az internetről 2009. január 15.).

Schüttler Tamás (2008): „Két új OECD kötetről, avagy hogyan függ össze az oktatásban érvényesülő méltányosság és a nem formális keretek között szerzett tudás”. Új Pedagógiai Szemle, 1. sz. 121-125. o.

http://www.oki.hu/oldal.php?tipus=cikk\&kod=2008-01-kj-Schuttler-Ket (letöltve az internetről 2009. január 15.).

Sz. Tóth János (szerk., 2004): Felnőttképzés az Európai Unióban, Kézikönyv az élethosszig tartó tanulásról II. Magyar Népföiskolai Társaság - Nemzeti Felnőttképzési Intézet, Budapest.

Tereseviciene, M. (szerk., 2007): Validation and recognition of experimental learning, Final book of the reaction project. VDU Egyetemi kiadó, Kaunas. 